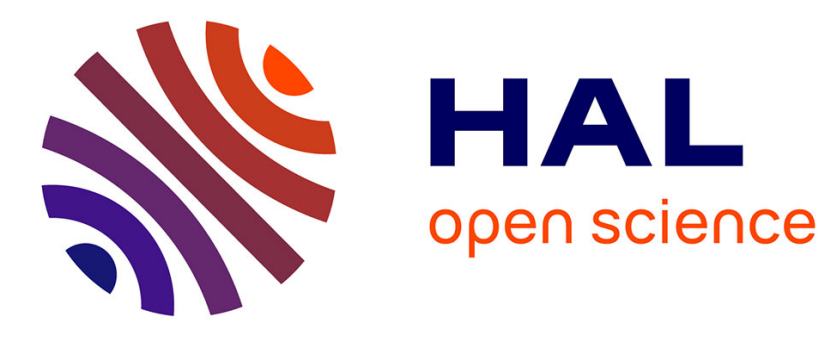

\title{
Concentration of floating biogenic material in convergence zones
}

Yves Dandonneau, Christophe E. Menkès, Olaf Duteil, Thomas Gorgues

\section{To cite this version:}

Yves Dandonneau, Christophe E. Menkès, Olaf Duteil, Thomas Gorgues. Concentration of floating biogenic material in convergence zones. Journal of Marine Systems, 2007, 69, pp.226-232. 10.1016/j.jmarsys.2006.02.016 . hal-00193692

\section{HAL Id: hal-00193692 \\ https://hal.science/hal-00193692}

Submitted on 4 Dec 2007

HAL is a multi-disciplinary open access archive for the deposit and dissemination of scientific research documents, whether they are published or not. The documents may come from teaching and research institutions in France or abroad, or from public or private research centers.
L'archive ouverte pluridisciplinaire HAL, est destinée au dépôt et à la diffusion de documents scientifiques de niveau recherche, publiés ou non, émanant des établissements d'enseignement et de recherche français ou étrangers, des laboratoires publics ou privés. 


\section{Concentration of floating biogenic material in convergence zones}

(by Yves Dandonneau ${ }^{\mathrm{a} *}$, Christophe Menkes ${ }^{\mathrm{a}}$, Olaf Duteil ${ }^{\mathrm{b}}$ and Thomas Gorgues ${ }^{\mathrm{a}}$ )

a IRD, IPSL-LOCEAN (CNRS-IRD-UPMC), 4 place Jussieu, 75252 Paris cedex 05, France

${ }^{\mathrm{b}}$ Departamento de Oceanografia Física, Instituto Oceanográfico, Universidade de São Paulo, Praça do Oceanográfico, 191, CEP 05508-900 - São Paulo - SP - Brasil

(Submitted to Journal of Marine Systems special issue on physical biological interactions) 


\begin{abstract}
:
Some organisms that live just below the sea surface (the neuston) are known more as a matter of curiosity than as critical players in biogeochemical cycles. The hypothesis of this work is that their existence implies that they receive some food from an upward flux of organic matter. The behavior of these organisms and of the associated organic matter, hereafter mentioned as floating biogenic material (FBM) is explored using a global physicalbiogeochemical coupled model, in which its generation is fixed to $1 \%$ of primary production, and decay rate is of the order of one month. The model shows that the distribution of FBM should depart rapidly from that of primary production, and be more sensitive to circulation patterns than to the distribution of primary production. It is trapped in convergence areas, where it reaches concentrations larger by a factor 10 than in divergences, thus enhancing and inverting the contrast between high and low primary productivity areas. Attention is called on the need to better understand the biogeochemical processes in the first meter of the ocean, as they may impact the distribution of food for fishes, as well as the conditions for air-sea exchange and for the interpretation of sea color.
\end{abstract}

Keywords: Sea Surface; Convergence; Biomass; 


\section{Introduction}

Research by marine biogeochemists is usually focused on the downward flux of particulate carbon as it is a critical component of the global carbon cycle. Conversely, the possibility that an upward flux exists has received little attention. Based on published observations, we assume here that this flux feeds an ecosystem that lives at the sea surface and we investigate how this ecosystem may be distributed by the ocean circulation. A common approach assumes that the atmospheric and radiative forcing maintains a well mixed layer below the surface, the depth of which approximately corresponds to the photic layer, or is even greater when deep convection occurs in some areas and seasons. Mixing implies that this layer is homogeneous, so that the study of its properties does not require complicated sampling schemes. In fact, on most oceanographic cruises, only a few seawater samples are routinely taken in the mixed layer, the first one being generally as deep as $5 \mathrm{~m}$, because taking samples closer to the surface may sometimes be difficult when sea conditions are rough. Given this context, specificities of the top centimeters of the ocean may have passed unnoticed.

On the other hand, the film at the surface of the ocean has received much attention, and it has been shown that many seawater components (such as lipids, bacteria and other material) are much more concentrated in the upper first microns than in the underlying water column (de Souza and Chrétienot-Dinet, 1984; Hardy, 1997). The scientific community interested in the surface film has developed dedicated instruments to collect water from this layer. Apart from a few articles which suggest that these concentrations should be the consequence of an upward flux (Wilson and Collier, 1972 ; Zutic et al., 1981), the links between this film and the underlying water column have not been intensively studied, and the nature and magnitude of such a flux has remained largely unknown.

Several recent publications point to singularities of the upper few centimeters of the ocean. Obernosterer et al. (2005) observe that net community production is always negative in this layer in the Mediterranean Sea, and conclude that excess of respiration must be counterbalanced by an upward flux of organic matter to the surface. Respiration rates in the upper two centimeters much higher than at $5 \mathrm{~m}$ depth have been measured in the northeastern subtropical Atlantic by Calleja et al. (2005). They additionally observe that the partial pressure of carbon dioxide is higher at $\sim 2 \mathrm{~cm}$ depth than at $5 \mathrm{~m}$ by typically $12 \mu \mathrm{atm}$, in conformity with the difference in respiration rates between these two layers. These observations strongly suggest that the gradient between the top centimeters at the surface of 
the ocean and deeper waters (at $\sim 5 \mathrm{~m}$ depth) is preserved in spite of the turbulence and convection that make the mixed layer homogeneous from a physical point of view (at least at the scale of the daily cycle). An explanation to this paradox - i. e. a strong biogeochemical gradient in a null or quasi null gradient of density - is that some biogenic materials float to the surface and remain there.

Floating biogenic material (FBM) may consist of detritus with attached bacteria and bubbles. It may also consist of organisms that float or swim at the sea surface and are referred to as the general terms neuston or pleuston (Zaitsev, 1997). This includes bacteria, microalgae, and larger animals, sometimes as surprising as velellas, snails or flying fishes. Pontellid copepods, which are adapted to live just below the surface and resist to ultra violet radiation, are abundant everywhere in the ocean (Champalbert, 1975). These animals need living or detrital particles as food for their metabolism and growth. They do not undergo vertical migrations that would enable them to feed at depth, so that their food must necessarily come up from deeper layers. Thus, their survival implies an upward flux of organic particles. Detection of such an upward flux in the ocean has seldom been undertaken. Using inverted sediment traps, Smith et al. (1989) found that it was typically $5-10 \%$ of the downward flux, and could be as high as two thirds, representing an unexpectedly high result. Their flux measurements however were at depths greater than $600 \mathrm{~m}$, and cannot be considered as representative of processes that occur near the surface. A process involving the coupling of bacteria with detritus, production of bubbles by metabolic activity, and floatability has been proposed (Haury et al., 1994). Recently, it has been shown that transparent exopolymer particles (TEP) could ascend to the upper ocean (Azetsu-Scott and Passow, 2004). TEP make up a large part of organic matter in the sea. They mostly consist of polysaccharides produced by algae during photosynthesis (Engel, 2002), and until now, they drew attention for their capacity to flocculate and contribute to the downward flux of particles (Engel et al., 2004). The observation by Azetsu-Scott and Passow (2004) shows that positively buoyant TEPs, which agglomerate some bacteria and protozoans, could be the vehicle for an upward flux of food for the ecosystem that grows at the surface.

Representation of biogeochemical fluxes in models at large scale (Aumont et al., 2003) or at mesoscale (Levy et al., 2001b) considers the particulate or dissolved organic matter that is passively advected by currents, and the negatively buoyant particles that sink and transfer organic matter from the photic layer to deeper waters, a process that maintains the vertical gradients of nutrients in the sea. FBM offers a different pathway : it rises to the surface, at a speed of about $14 \mathrm{~m} \mathrm{~d}^{-1}$ (Azetsu-Scott and Passow, 2004), and may serve as food 
for an ecosystem that lives near the surface. More interestingly, the resulting biomass remains at the surface, either because of its low density, or because of its swimming behaviour, and consequently, it does not follow the water masses when they are downwelled. Consequently, it will be concentrated by convergence of the surface currents. Floatability of FBM and attraction to the surface may thus result in a distribution of this biomass drastically different from the biomass that is neutrally buoyant. While FBM may not be abundant enough to represent an important component of global ocean fluxes, its behaviour merits investigation.

\section{Methods}

As explained above, biological and biogeochemical observations just below the surface are too scarce, and we use here a model to simulate the distribution of FBM. Given the diversity of the neuston and pleuston, and the lack of knowledge of their controls and dynamics, this model is necessarily very simple. We only aim to investigate the major differences between the distribution of FBM, and that of neutrally or negatively buoyant organic matter that is the object of most biogeochemical studies. We used the global ORCA 2 version of the Océan PArallélisé primitive equations model (Madec et al., 1998) restricted to the $30^{\circ} \mathrm{N}-30^{\circ} \mathrm{S}$ belt. Its grid is $2^{\circ} \times \cos$ (latitude) in latitude $\left(0.5^{\circ}\right.$ near the equator), $2^{\circ}$ in longitude, and there are 31 depth levels, with $10 \mathrm{~m}$ spacing in the top $200 \mathrm{~m}$. The model is forced daily by a combination of ERS 1-2 scatterometer and TOGA-TAO in situ wind stress (Menkes et al., 1998) from 1992 to 2000, as in Lengaigne et al. (2003), and with NCEP heat and freshwater fluxes (Kalnay et al. 1996). It is closed at its northern and southern boundaries, with no damping, as this has been shown to preserve the performance of the model in the $10^{\circ} \mathrm{N} 10^{\circ} \mathrm{S}$ band (Vialard et al., 2001; Menkes et al., accepted).

This physical model is coupled on line to the PISCES bio-geochemical model (Aumont et al., 2003) which simulates the main biogeochemical fluxes, including primary production. The coupling of these two models produces realistic simulations of the physical and biogeochemical conditions in the ocean, especially at low latitudes (Aumont et al., 2003; Gorgues et al., 2005). FBM has been added to the PISCES model. Its generation is indexed on modeled primary production (an output of PISCES), in conformity with Engel (2002). It is immediately added in the upper first interval $(10 \mathrm{~m})$ in the model grid. Finally, a decay rate was applied. The evolution with time of FBM is thus given by :

$$
\partial F B M / \partial t=-u \partial F B M / \partial x-v \partial F B M / \partial y-F B M / \tau+P f \times P P
$$


where $t$ is time, $u$ and $v$ are the zonal and meridional components of horizontal velocity, and $\tau$ is a time scale of decay. $P P$ is the modeled primary production, and $P f$ is the fraction of primary production that feeds FBM production and is injected is the first level of the grid. FBM is transported in the modeled ocean as a tracer (Lévy et al., 2001a), according to the MUSCL advection scheme (we neglect here the horizontal diffusion). However, as floatability makes it to remain at the surface, vertical velocity and vertical diffusion for this tracer have been set to null values (hence the absence of a vertical transport term in the above equation). Pf has been set to $1 \%$ and the interaction of FBM production with other organic carbon pools in PISCES has been neglected. We adopted a time scale of decay equal to 30 days (leading to equilibrium between gain and loss after about six months).

\section{Results}

As expected, the outputs of the model between $30^{\circ} \mathrm{N}$ and $30^{\circ} \mathrm{S}$ show that the distribution of FBM is drastically different from that of chlorophyll or primary production that generally exhibit higher values at the equator than on both sides (Fig. 1a): on the contrary, FBM is low at the equator in the Pacific Ocean $\left(0.06\right.$ to $\left.0.12 \mu \mathrm{M} \mathrm{C}^{-1}\right)$, and high on both sides at latitudes between 4 and $10^{\circ}\left(0.6 \mu \mathrm{M} \mathrm{l}^{-1}\right)$. Further, while chlorophyll concentration is typically $0.06 \mu \mathrm{g}^{-1}$ in oligotrophic areas, and 0.20 at the equator, i. e. a three-fold increase, FBM varies by a factor $\sim 10$ in this area. The same pattern can be seen in the Atlantic Ocean where the equator has low FBM concentrations, contrasting with the belts at $5^{\circ}$ on both sides of the equator. In the Indian Ocean, the situation is quite different : the equator there is marked by a line of high FBM concentration bounded to the south by very low values, and a larger patch of high FBM concentrations occupies the western Arabian Sea. Apart from these offshore large scale structures, spots with high concentrations are located near islands north of Australia, Papua New Guinea and Borneo, and in low-latitude western boundaries currents. Well known upwelling areas such as the equator and the Costa Rica dome in the Pacific, and tropical coastal upwellings, show the lowest FBM concentrations. The high concentrations to the north and south limits of the modeled domain are a consequence of the closure of circulation at $30^{\circ}$ with no dumping, and do not deserve attention. Overall, Figure $1 \mathrm{a}$ and $1 \mathrm{~b}$ strongly suggest a) that FBM is accumulated in convergence areas such as those between the South Equatorial Current and the North and South Equatorial Counter Currents, b) that the 
distribution of FBM is radically different from that of oceanic productivity, and c) that FBM
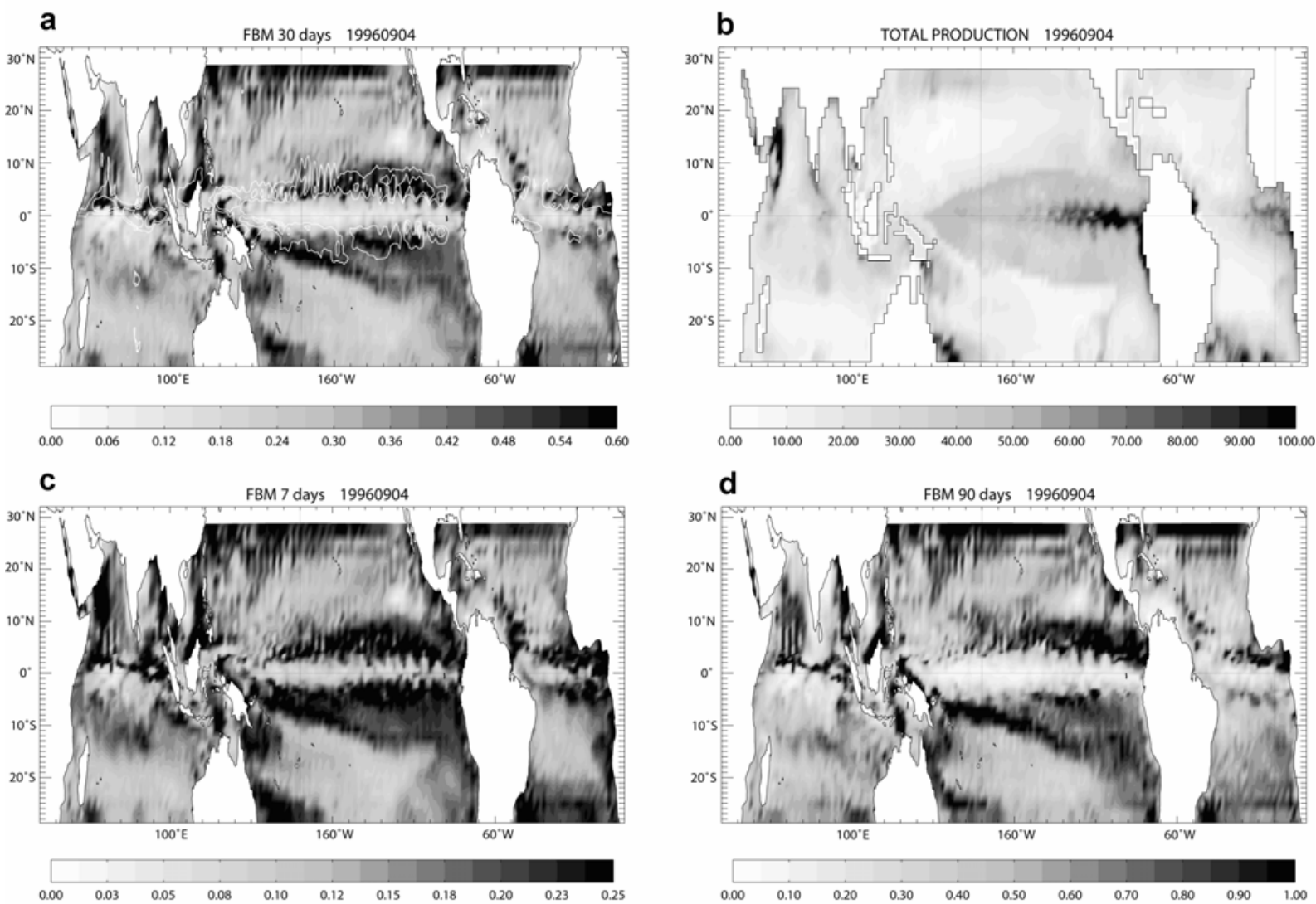

Fig. 1. (a) Modeled FBM distribution ( $\mu M \mathrm{Cl}^{-1}$ in the upper $10 \mathrm{~m}$ layer) on September 4, 1996 (the time scale of FBM decay is 30 days) and convergence contours (downward velocity of -0.25 $\mathrm{m} \mathrm{d}^{-1}$ in the 10 to $70 \mathrm{~m}$ depth layer). (b) Modeled primary production ( $\mathrm{mMC} \mathrm{m}^{-2} \mathrm{~d}^{-1}$ ) at the same date. (c) Identical to (a), except time scale of decay set to 7 days. (d) Identical to (a), except time scale of decay set to 90 days. Note that the gray scale is different for panels (a), (c) and (d).

dynamics simulated by this model generate a spatial distribution much more contrasted than that of chlorophyll.

Since FBM mostly originates from productive upwelling areas, and, after transport, accumulates in convergences of surface currents, the life length of FBM plays an important role. A very short time scale of decay would not permit FBM produced in high productivity areas to reach convergence zones. Yet, with the time scale of decay set to 7 days instead of 30 days, FBM is still removed from the productive equatorial upwelling (Fig. 1c), while to a lesser extent than in the reference experiment. We examined this point in the tropical instability waves (TIWs) system in the equatorial Pacific, as it is suggested by Figure 1a that 
these TIWs modulate the distribution of FBM. The strong coupling between the physics and biology in TIWs in the Atlantic Ocean has been described by Menkes et al. (2002). We initialized the model placing FBM constant in a 95 to $115^{\circ} \mathrm{W}, 2{ }^{\circ} \mathrm{N}$ to $2^{\circ} \mathrm{S}$ zone, and then advected it with no more additional FBM production. FBM is very quickly trapped by convergences, as shown on Figure 2b, which corresponds to a five days drift. On day 10, FBM is being exported polewards; it follows temperature fronts on the leading edge of the vortices, making thin lines which mimic the "line in the sea" (Yoder et al., 1994). On day 20, the equator has been washed out and FBM is totally transferred in the neighboring convergence zones to the north and the south. Thus, the transfer of FBM from divergent productive areas to trapping convergence zones is a fast process that occurs in a few days. Longer time scale of decay globally increase the amount of FBM but do not change much its distribution : figure $1 \mathrm{~d}$ where this time scale was set to 90 days differs from figure 1a by the higher FBM modeled concentrations but the detailed structure is not changed.

\section{Discussion}

These results indicate that the distribution of FBM is controlled by the ocean surface circulation, rather than by primary production. Our general term FBM includes all dead or living particles that are transported by the surface current and do not sink when the current is downward. It is thus defined by its physical properties and behaviour. Its life cycle and taxonomic membership are diverse and largely unknown. Bacteria, coelenterates, crustaceans or other components of the neuston present a very wide range of life length (from less than one hour for photosensitive organic matter to years for fishes such as Mola mola. It is impossible now to assign to it a precise time rate of decay. Certainly, the particulate organic matter that reaches the sea surface has a short life. But the animals that feed on it are adapted to exposition to high ultra violet radiation near the surface and may live several months. The 30 days time scale of decay that we used in the modelling experiment is rather long, and corresponds to the living animals, such as the Pontellid copepods, rather than to the non living particles. This time scale of decay leads to equilibrium between gain and loss after about six months. Our results (Figs. 1 and 2) indicate that after a few days, the patterns of FBM distribution are already fixed. The fraction of primary production $(P f)$ that is immediately converted into FBM, was arbitrarily set to $1 \%$. This value is much less than reported values of excretion of organic matter by the phytoplankton (Sakshaug, 1993). It makes FBM very small compared to the non-FBM organic matter pools simulated by PISCES, so that neglecting the retroaction of FBM on these pools probably has very little impact. The combination of $P f$ and 
$\tau$ determines the total amount of FBM, but these parameters are unknown and need to be evaluated during process studies at sea.

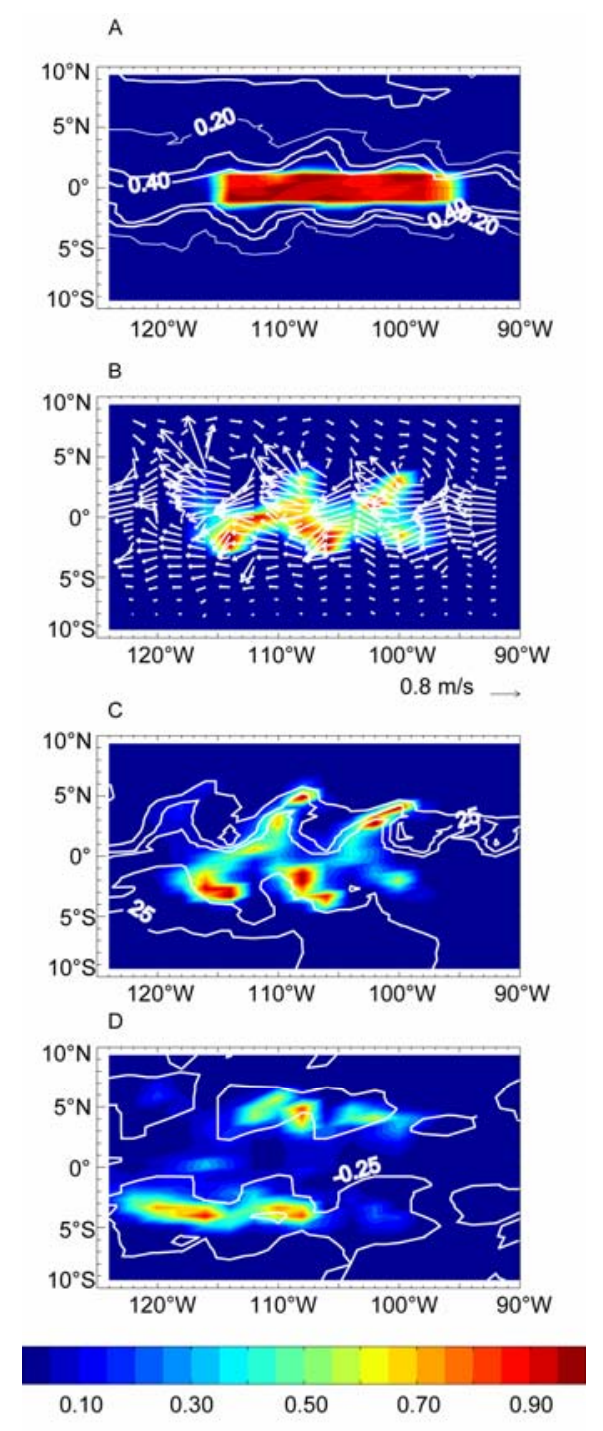

Fig. 2. migration of FBM in tropical instability waves. FBM is placed in a 95 to $115^{\circ} \mathrm{W}, 1^{\circ} \mathrm{N}$ to $1{ }^{\circ} \mathrm{S}$ zone at time zero (September 2, 1996), and then advected by surface currents. (a) day 2, with superimposed modeled chlorophyll contours ( $\mu \mathrm{g}$ l-1). (b) day 5, with superimposed surface current vectors. (c) day 10, with superimposed sea surface temperature contours. (d) day 20, with superimposed average downward vertical velocity contours ( $m d-1$ ) in the $10-$ 70 m upper layer.

The decoupling of seawater and of one of its constituents caused by the floating behaviour of FBM plays a key role here, as it is potentially responsible for the build up of very strong gradients in the ocean. The coarse grid of the ORCA-2 model version that we 
used does not resolve the mesoscale circulation, and does not generate the many small scale eddies that are thought to be important for the forcing of marine biogeochemical fluxes (Lévy et al, 2001b). The distribution of FBM that we simulated here (Fig. 1) is certainly a smoothed representation of what may happen in the ocean. One can expect that higher resolution models can reproduce mesoscale eddies, and that the potential for FBM trapping in these eddies will prove to be high. At this exploratory step, it would be premature to use a sophisticated model while the nature, sources and sinks of FBM are so poorly known.

The convergence areas where FBM tends to accumulate usually have low biological activity. In addition, the distribution of FBM is much more contrasted than that of primary production. It is also different from the distribution of zooplankton drawn by Vinogradov (1981) : the zooplankton maxima on both sides of the equator in the Pacific Ocean, which can be understood as derived from primary production after a maturation delay, are closer to the equator than the FBM maxima. This provides a new way to understand the distribution of higher predators that feed on species living at the surface : the migrations of these predators might be controlled more tightly by the physical process of convergence than by food chains, because primary production - the source of FBM - only varies by a factor $\sim 3$ while FBM varies by a factor 10. There is a very strong analogy between FBM and the tuna forage modelled by Lehodey et al. (1998). The later is defined as the food that is transferred from primary productivity to carnivorous zooplankton after an average 2.5 trophic levels transfer, and is advected by surface currents.

In the FBM enriched convergence zones, the commonly accepted idea that optically active components of seawater are in constant proportions, on which the concept of case I waters is based (Morel and Prieur, 1977), may not apply, since there should be an excess of detritus and non algal cells compared to the average properties of the ocean. The resulting effect of abnormally abundant light diffusing particles on the transfer of light in the upper ocean layers might be high enough to create anomalies in seawater color: an upward flux of biogenic matter, further concentrated in the convergence zones that occur in the poleward sector of eddies (Tomczak and Godfrey, 1994), has been shown to potentially explain anomalies in chlorophyll concentration detected from satellite, associated to Rossby waves that propagate westward in the oligotrophic subtropical gyres (Dandonneau et al., 2003).

\section{Conclusion}


Accumulation of floating material along fronts is a common observation, but has not yet received attention as being a process of interest tightly dependent on the biogeochemistry and on the physics of the ocean. Addition of FBM in a coupled physical - biogeochemical model shows that the ocean circulation operates an efficient separation of FBM from seawater in the ocean divergences and convergences. Concentrations by a factor 10 are generated in a coarse grid ocean circulation model that only resolves the large scale circulation patterns such as the equatorial currents system and the tropical instability waves. Thus, it can be expected that models at higher resolution, which resolve the Rossby waves, the mesoscale and submesoscale circulation, the associated convergences and divergences, and their biogeochemical consequences (Mahadevan and Archer, 2000; Lévy et al., 2001b), will generate much higher concentration factors.

If FBM occurs only in negligible amounts, and decays rapidly, the impact of the concentration process will be small. There are however many indications suggesting that a significant upward flux is active, and feeds a population well adapted to survive at the surface. Then, very strong gradients of FBM can potentially be generated in the ocean, with a spatial distribution radically different from that of marine productivity. These specificities of FBM have at least three major important implications. First, as noted by Calleja et al. (2005), concentration of life and enhanced respiration in the upper centimeters of the ocean may modify the conditions at the interface, especially for air-sea exchange of carbon dioxide. Second, as circulation decouples FBM from the other biogeochemical tracers with neutral or negative buoyancy, and present interpretation of sea color is based on constant ratios of chlorophyll a to other seawater optically active components, accumulations of FBM may cause a positive bias on the chlorophyll estimates based on satellite detected sea color, as in Dandonneau et al. (2003). Third, concentration of food in convergence zones (generally poor in major nutrients) may be a factor in understanding how and why higher level predators survive and concentrate in low productivity areas. There is a need for a focus on the biogeochemistry of the ocean first meter, which has generally been neglected, for a better knowledge of the biomass that grows and decays there, and of its dynamics. This will be possible only if new sampling strategies are implemented, and in some domains, if new instrumentation is developed.

Acknowleldgements : We are grateful to the four anonymous reviewers for their pertinent comments. Sean Kennan read the manuscript and improved the English. Olaf Duteil's grant is from the University of Sao Paulo. 


\section{References}

Aumont, O., Maier-Reimer, E., Blain, S., Monfray, P., 2003. An ecosystem model of the global ocean including Fe, Si, P colimitations. Global Biogeochemical Cycles 17 (Art. No GB1060).

Azetsu-Scott, K. Passow, U., 2004. Ascending marine particles : significance of transparent exopolymer particles (TEP) in the upper ocean. Limnology and Oceanography, 49 (3), 741-748.

Calleja, M.L., Duarte, C.M., Navarro, N., Agustí, S., 2005. Control of air-sea CO2 disequilibria in the subtropical NE Atlantic by planktonic metabolism under the ocean skin. Geophysical Research Letters 32 (Art. No L08606).

Champalbert, G., 1975. Répartition du peuplement animal de l'Hyponeuston, étude expérimentale de la physiologie et du comportement des pontellidés. $\mathrm{PhD}$ dissertation, University of Aix-Marseille, 312 pp.

Dandonneau, Y., Vega, A., Loisel, H., du Penhoat, Y., Menkes, C., 2003. Oceanic Rossby waves acting as a "hay rake" for ecosystem floating by-products. Science 302, 1548-1551.

De Souza, Y.,Chretiennot-Dinet, M.J., 1984. Measurements of biomass and activity of neustonic microorganisms. Estuarine and Coastal Shelf Science 19, 167-180.

Engel, A., 2002. Direct relationship between $\mathrm{CO}_{2}$ uptake and transparent exopolymer particles production in natural phytoplankton. Journal of Plankton Research 24, 49-53.

Engel, A., Thoms, S., Riebesell, U., Rochelle-Newall, E., Zondervan, I., 2004. Polysaccharide aggregation as a potential sink of marine dissolved organic carbon. Nature 428, 929-932.

Gorgues, T., Menkes, C., Aumont, O., Vialard, J., Dandonneau, Y., Bopp, L., 2005. Biogeochemical impact of Tropical Instability Waves in the Equatorial Pacific. Geophysical research Letters 32 (Art. No L24615). 
Hardy, J. T., 1997. Biological effects of chemicals in the sea-surface microlayer. In : Liss P. S., Duce, R. A. (eds) The sea surface and global change, Cambridge University Press, Cambridge, 339-370.

Haury, L.R., Fey, C.L., Shulenberger, E., 1994. surface enrichment of inorganic nutrients in the North Pacific Ocean. Deep-Sea Research I 41, 1191-1205.

Kalnay, E., Kanamitsu, M., Kistler, R., Collins, W., Deaven, D., Gandin, L., Iredell, M., Saha, S., White, G., Woollen, J., Zhu, Y., Chelliah, M., Ebisuzaki, W., Higgins, W., Janowiak, J., Mo, K.C., Ropelewski, C., Wang, J., Leetmaa, A., Reynolds, R., Jenne, R., Joseph, D., 1996. The NCEP/NCAR 40-Year Reanalysis Project. Bulletin of the American Meteorological Society 77, 437-470.

Lehodey, P., André, J.-M., Bertignac, M., Hampton, J., Stoens, A., Menkes, C., Memery, L., Grima, N., 1998. Predicting skipjack tuna forage distributions in the equatorial Pacific using a coupled dynamical bio-geochemical model. Fisheries Oceanography 7, 317-325.

Lengaigne, M., Madec, G., Menkes, Alory, G., 2003. Impact of isopycnal mixing on the tropical ocean circulation. Journal of Geophysical Research, 108, 3345-3358.

Lévy, M., Estublier, A., Madec, G., 2001a. Choice of an advection scheme for biogeochemical models. Geophysical Research Letters 28, 3725-3728.

Lévy, M., Klein, P., Tréguier, A.-M., 2001b. Impact of submesoscale physics on production and subduction of phytoplankton in an oligotrophic regime. Journal of Marine Research $59,535-565$.

Madec, G., Delecluse, P., Imbard, M., Lévy, C., 1998. OPA 8.1 ocean general circulation model reference manual. Notes du pôle de modélisation de l'Institut Pierre-Simon Laplace $91 \mathrm{pp}$.

Mahadevan, A., Archer, D., 2000. Modeling the impact of fronts and mesoscale circulation on 
the nutrient supply and biogeochemistry of the upper ocean. Journal of Geophysical Research, 105, 1209-1225.

Menkes, C., Boulanger, J.-P., Busalacchi, A. J., Vialard, J., Delecluse, P., McPhaden, M. J., Hackert, E., Grima, N., 1998. Impact of TAO vs. ERS wind stresses onto simulations of the tropical Pacific Ocean during the 1993-1998 period by the OPA OGCM, Climatic Impact of Scale Interactions for the Tropical Ocean-Atmosphere System. Euroclivar Workshop Report, 13, 46-48.

Menkes, C.E., Kennan, S.C., Flament, P., Dandonneau, Y., Masson, S., Biessy, B., Marchal, E., Eldin, G., Grelet, J., Montel, Y., Morlière, A., Lebourges-Dhaussy, A., Moulin, C., Champalbert, G., Herbland, A., 2002. A whirling ecosystem in the equatorial Atlantic. Geophysical Research Letters 29 (Art.No 1553).

Menkes, C., Vialard, J., Kennan, S. C., Boulanger, J.-P., Madec, G., in press. A modelling study of the three-dimensional heat budget of tropical instability waves in the equatorial Pacific. Journal of Physical Oceanography.

Morel, A., Prieur, L., 1997. Analysis of variations in ocean color. Limnology and Oceanography 22, 709-722.

Obernosterer, I., Catala, P., Reinthaler, T., Herndl, G.J., Lebaron, P., 2005. Enhanced heterotrophic activity in the surface microlayer of the Mediterranean Sea . Aquatic Microbial Ecology, 39, 293-302.

Sakshaug, E., 1993. The relationship between phytoplankton growth rate and production with emphasis on respiration and excretion. ICES Marine Science Symposia 197, 63-68.

Smith, K.L., Williams, P.M., Druffel, E.R.M., 1989. Upward fluxes of particulate organic matter in the deep north Pacific. Nature, 337, 724-726.

Tomczak, M., Godfrey, S., 1994. Regional Oceanography : an introduction. Pergamon Press, New York 422 p. 
Vialard, J., Menkes, C., Boulanger, J.-P., Delecluse, P., Guilyardi, E., McPhaden, M. J., Madec, G., 2001. A Model Study of Oceanic Mechanisms Affecting Equatorial Pacific Sea Surface Temperature during the 1997-98 El Niño. Journal of Physical Oceanography, $31,1649-1675$.

Vinogradov, M., 1981. Ecosystems of equatorial upwellings. In : Analysis of Marine Ecosystems, A. R. Longhurst (ed.), Academic Press, London, 69-93.

Wilson, W.B., Collier, A., 1972. The production of surface active material by marine phytoplankton cultures. Journal of Marine Research 30, 15-26.

Yoder, J.A., Ackleson, S.G., Barber, R.T., Flament, P., 1994. A line in the sea. Nature 371, 689-693.

Zaitsev, Y.P. 1997. Neuston of seas and ocean. . In: P. Liss, R. Duce (Eds), The Sea Surface and Global Change. Cambridge University Press, N.Y.: 371-382.

Zutic, V., Cosovic, B., Marcenko, E., Bihari, N., Krsinic, F., 1981. Surfactant production by marine phytoplankton. Marine Chemistry 10, 505-520.

* Corresponding author. Present address : LOCEAN, Tour 45-55, $5^{\text {ème }}$ étage, Université Pierre et Marie Curie, 4 place Jussieu, 75252 Paris cedex 05, France. Tel +33 14427 4765; fax +33144273805

E-mail address : yd@lodyc.jussieu.fr 